\title{
Correction to: Phylogenetic relationships in Stephanopinae: systematics of Stephanopis and Sidymella based on morphological characters (Araneae: Thomisidae)
}

\author{
Miguel Machado $^{1}$ (D) $\cdot$ Renato Augusto Teixeira $^{1}$ \\ Published online: 5 February 2021 \\ (C) Gesellschaft für Biologische Systematik 2021
}

Correction to: Organisms Diversity \& Evolution https://doi.org/10.1007/s13127-020-00472-x

The original version of this article contained errors. The legends of Figs. 2, 3, 4, 8, 9, 10, 12, 13, 15, 16, 17, 19, 20 and 21 were shown in the wrong order. The image of Fig. 2 belongs to Fig. 3 and vice versa. The original article has been corrected.

Publisher's note Springer Nature remains neutral with regard to jurisdictional claims in published maps and institutional affiliations.

The online version of the original article can be found at https://doi.org/ 10.1007/s13127-020-00472-x

\footnotetext{
Miguel Machado

machadom.arachno@gmail.com

1 Laboratório de Aracnologia, Escola de Ciências da Saúde e da Vida, Pontifícia Universidade Católica do Rio Grande do Sul (PUCRS),

Porto Alegre, Rio Grande do Sul, Brazil
} 